\title{
DYTISCUS PICEUS.
}

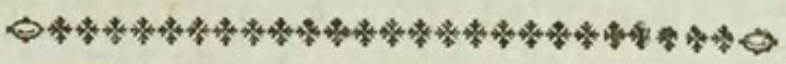

CHARACTER GENERICUS.

Antenna fetaceæ, aut clavato-perfoliatæ. Pedes poftici villofi, natatorii, fubmutici.

$$
\text { Lin. Syft. Nat. p. } 66_{4} .
$$

CHARACTER SPECIFICUS, EC.

DYTISCUS niger nitidus, antennis perfoliatis, fterno poftice mucronato.

DYTISCUS antennis perfoliatis, corpore lævi, fterno carinato, poftice mucronato.

$$
\text { Lin. Syf. Nat. p. } 664 .
$$

HYDROPHILUS ruficornis.

$$
\text { Degeer. 4. p. 371.t. 14. f. 1. } 2 .
$$

DYTISCUS haftatus.

$$
\text { Herbft. Befch, der naturf. Berl. Fr. }
$$

HYDROPHILUS niger, \&c.

$$
\text { 4.t. } 7 \cdot f \cdot 2 .
$$

Geoffr. inf. Par. 1. p. 182. t. 3. f. 1. SCARABEE, \&c.

$$
\begin{array}{r}
\text { Lyonet Leff. t. 2. p. 54. n. 110. t. } 1 . \\
\text { f. } 15^{-17} .
\end{array}
$$

Omnium qui in Britannia generantur maximus eft Dytifcus piceus. A cæteris facillime dignofcitur, quippe 
quippe qui totus nigerrimus thoracem inferiorem folus gerat mucronatum; quod non nifi paucis exoticis contingit, nulli præter hunc Britannico. Aliæ licet fpecies magis abundent, hujus tamen nulla eft penuria. Pifcinas amat aquafque ftagnantes, larvaque ejus ut et alicrum Dytifcorum atrociffime prædatur teneriora infecta, nec non vermes et pifciculos, quos oris forcipibus correptos fugendo enecat. Hujus aliorumque majorum Dytifcorum juniores ab antiquioribus phyficis nomine Squillarum aquaticarum defcribi foliti funt; effe cnim cos revera larvas tunc temporis ignorabant. Licet inter larvas diverfarum fpecierum maxima fit fimilitudo, hujus tamen creteris major fibi peculiare quiddam habet et anomalum, cui vix fimile in aliis animalibus invenias : crura nempe, ni penitius examinentur, non ut aliorum infectorum, fub thorace fita videntur, fed fupra, indeque ad latera deflecti. Crura autem non revera dorfo inferuntur, fed oritur deceptio a peculiari quadam conformatione fituque capitis ; augetque deceptionem larvæ tum natantis tum quiefcentis inverfa plerumque pofitio; adeo ut difficile fit vel exercitatifimo phyfico errorem femel conceptum ex animo excutere. Frifchius in hiftoria infectorum ne minimum dubitaffe videtur crura reapfe effe dorfo inferta : et celeberrimus Reaumurius cum huic fimile aliquod in alio infecto aquatico obfervaffet, attonitus rei novitate phænomenon unicum nec alibi ufpiam confpectum commemoravit. Auctor quoque quarti voluminis Sebr Thefauri lectores fedulo admonet, fculptorem corrigere volentem quod falfo et infcite delineatum putavit, pedes hujus larvæ non fupra thoracem 
thoracem fed fubtus depinxiffe. Lyonettus autem, multo vir acumine, in notas quas adjecit libro Lefferi, cui titulus "Theologie des Infectes," errorem vulgarem primus videtur detexiffe, et veram larvæ conformationem luculenter defcripfiffe.

Dytifcorum larvæ non nifi poft duos? circiter annos in pupas feu chryfalidas transformantur: cum enim ad plenam magnitudinem pervenerint, in cavo aliquo ripæ latibulo torpidæ aliquandiu dormiunt; deinde cutim exuunt et chryfalides fiunt. Elapfo certo tempore, iterum exuviæ abjiciuntur, ipfeque Dytifcus jam plene formatus erumpit; qui chryfalidis cute primum depofita, tenerrimus eft et coloris pallidi; paucis vero horis elytra feu alarum tegumenta fatis indurantur, colore gradatim magis magifque fufco donec penitus nigraverit; et tum demum infeetum nova gaudens forma, nec alias ullas vices fubiturum, aquis fe audacter concredit.

Mares Dytifcos diftinguit a feminis crurum anticorum diverfitas, quæ juxta pedum infitionem concava quadam cornea et rotundata parte velut clypeolo inffruuntur, quo prorfus carent crura feminea. Toti generi peculiaris eft et miranda crurum pofticorum formatio, quorum latera interiora ferie pilorum longorum et denforum obfita funt, pinnas quodammodo referentium; quibus magnopere in natando adjuvantur. Notandum porro eft Dytifcum feminam fpeciei jam depictæ exemplum præbere artis, aliis (ut videtur) infectis coleoptratis penitus incognitæ; telam nempe nendi complanatam, circularem, fericam, quam fuper aquas libere fluitantem relinquit, ibique ova fua deponit; cujufque fuper- 
fuperficies fuperior cornu in formam quafi coni crefcente terminatur, longo, fufco, et denfiori ipfa theca, quæ albet. Larvæ ut primum a thecæ carcere liberantur, aquis fe illico credunt. Quod mirum in hiftoria Dytifci primus notavit Dominus Lyonettus.

Cavendum eft putemus Dytifcos non poffe fub dio vivere; frequenter enim per prata vagantur, in hanc vel illam aquam ad libitum fe recipientes: quod cum noctu præcipue fiat, non mirum eft fi ignoretur. $\mathrm{Si}$ incaute ex aquis nuda manu excipiatur Dytifcus piceus, eo eft robore ut cutim mucrone thoracico interdum luctando vulneret. 

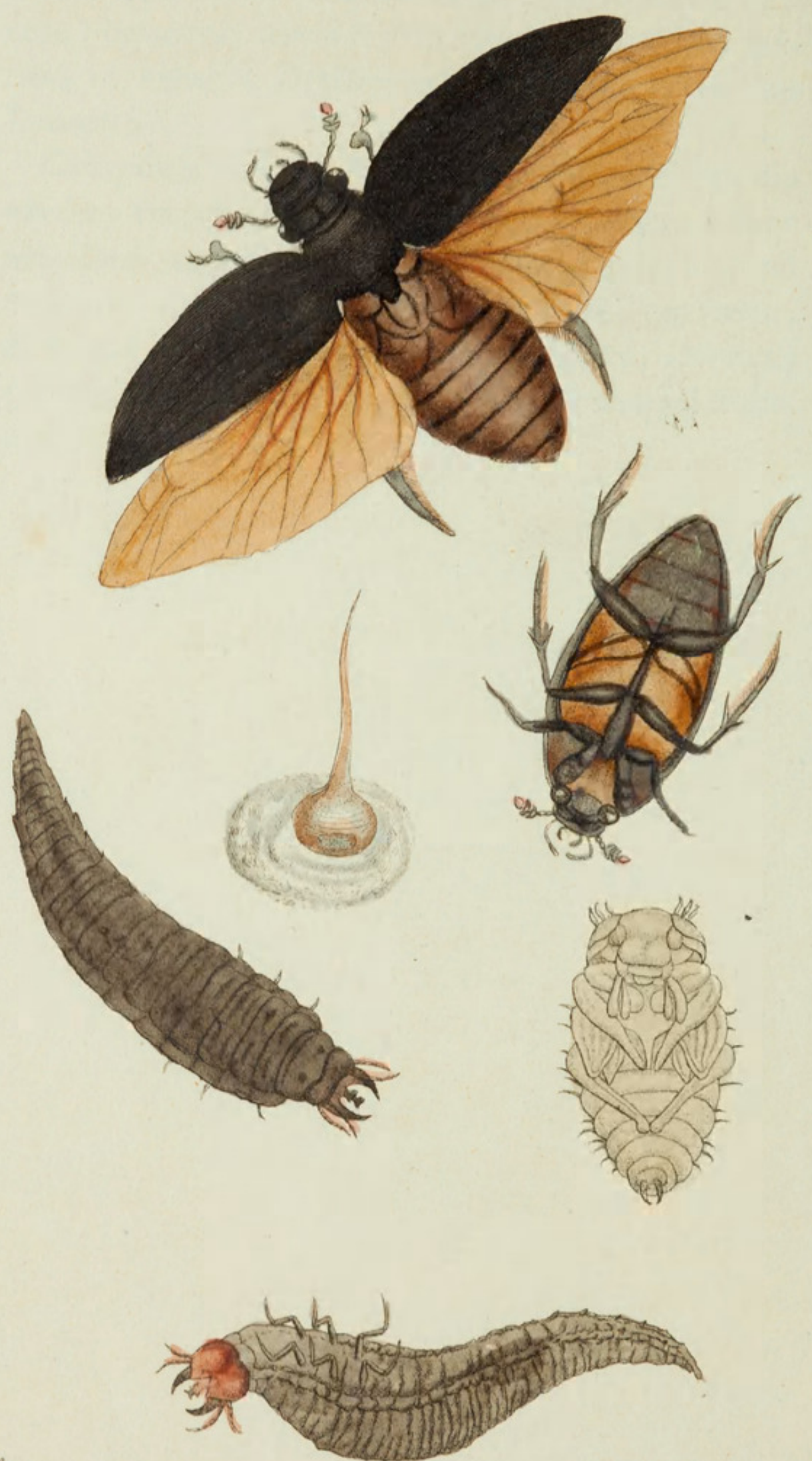


\section{THE}

\section{GREAT DYTISCUS.}

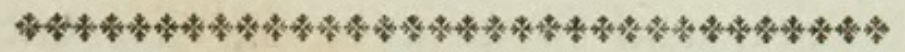

\section{GENERIC CHARACTER.}

Antennce either fetaceous or clavato-perfoliate.

Hind Feet formed for fwimming, villofe on the interior fide, and farce perceptibly clawed.

\section{SPECIFIC CHARACTER, EंC.}

Gloffy-black DYTISCUS, with perfoliate antennæ and long thoracic fpine pointing backwards.

The large Black WATER-BEETLE.

The Spiked WATER-CLOCK.

Grere. Muf.p. 170.

The infect here figured is the largeft of all the Britifh Dytifci, and is at once diftinguifhed by its uniform blacknefs, and by the remarkable fpine or procefs proceeding from the lower part of the thorax; and which, though occurring in fome exotic Dytifci, is found in no other Britifh fpecies. It is not a very uncommon animal, though far more fo than fome others of the genus. It is found in ponds and ftagnant waters; where its larva, like thofe of other 
other fpecies, commits great havoc amongft the more tender aquatic infects, as well as amongft worms and young firh, which it feizés with its forcipated jaws, and deftroys by fucking out their juices. The larvæ of the larger Dytifci were defcribed by the older writers on natural hiftory under the title of Squille aqualica; and were not at that time known to be Dytifci in their firft or caterpillar ftate. There is a great fimilarity between the larvæ of the different Dytifci; but that of the prefent fpecies is diftinguifhed by a particularity fo very remarkable as fcarce to be equalled by any other creature. This confifts in the apparently anomalous fituation of the legs; which feem, unlefs very accurately examined, to be placed, not beneath the thorax, as in other infects, but on the upper part, and from thence to be deflected towards the fides. This uncommon appearance however is not owing to a real dorfal inftead of ventral infertion of the legs, but principally to the peculiar thape and pofition of the head; and the deception is fo much heightened by the inverted pofture in which the infect generally fwims and refts, that it is by no means eafy even for the moft fcientific obferver to divent himfelf of the erroneous idea before mentioned. Frifch, in his Hiftory of Infects, appears to have been completely convinced of the real dorfal infertion of the legs; and the celebrated Reaumur, having difcovered fomething fimilar in another aquatic infect, was fo ftruck with the unufual appearance, that he has commemorated it as a circumftance unparalleled in the animal world. The author of 
the fourth volume of Seba's Thefaurus was of the fame opinion, and exprefsly warns his readers that his engraver, thinking to rectify what he fuppofed an erroneous drawing, has reprefented the legs in this larva as fituated beneath the thorax, and not on the upper part. The fagacious Lyonett, in his obfervations on Leffer's "Theologie des Infectes," feems to have been the firft who detected the common error, and afcertained the real ftructure of the animal, which he has clearly and fatisfactorily explained.

The larvæ of the Dytifci remain about two? years before they change into pupæ or chryfalides. When the larva is arrived at its full growth, it fecretes itfelf in the bank of the water it inhabits, and having formed a convenient cavity or cell, lies dormant for fome time; after which it divefts itfelf of its fkin, and appears in the form of a chryfalis; in which ftate having continued for fome time longer, it again delivers itfelf from its exuviæ, and appears in its complete or Beetle form. When firft difengaged from the fkin of the chryfalis, it is of a pale color, and very tender: in the fpace however of a few hours, the elytra or wing-cafes acquire a degree of ftrength and a dark color, which gradually grows more and more intenfe, till the animal, finding itfelf fufficiently ftrong, comes forth from its retreat, and commits itfelf in its new form to the waters.

The male Dytifci are diftinguifhed from the females by the ftructure of the fore legs, which are furnifhed, near the fetting on of the feet, with a fort of horny, concave flap or fhield: the legs of the 
females are deftitute of this part. The ftructure of the hind legs, in the whole genus Dytifcus is fingularly curious, and finely calculated for their aquatic mode of life; being furnifhed on the interior fide with a feries of long and clofe-fet filaments, fo as to give a fort of finny appearance to the legs, and to enable the animal to fwim with the greateft eafe and celerity. It may be added that the female of the Dytifcus piceus affords an example of a faculty which feems to be exercifed by no other coleopterous infects; viz. that of fpinning a kind of web or flattifh, circular cafe of filk, which it leaves floating on the furface of the water, and in which it depofits its eggs : this cafe is terminated on its upper furface by a lengthened, conical procefs refembling a horn; of a brown color, and of a much ftronger or denfer nature than the cafe itfelf, which is white. The young larvæ, as foon as hatched, make their efcape from the envelopement of the cafe, and commit themfelves to the water. This curious particular in the hiftory of the Dytifcus piceus was firft difcovered by Lyonett.

It is not to be imagined that becaufe the Dytifci are fo generally feen in the water, they are therefore incapable of living in air: on the contrary, they fometimes emerge, and fly about the fields, and thus migrate from water to water: but as this happens chiefly by night, it is not generally obferved.

The Dytifcus piceus is an infect of great ffrength, and if incautioufly handled when taken out of the water, will ftruggle in the hand with fo much force as fometimes to wound the fkin with its thoracic fpine. 


\section{$2 \mathrm{BHL}$ Biodiversity Heritage Library}

Shaw, George. 1797. "The Great Dytiscus, Dytiscus piceus [PI. 292]." The Naturalist's Miscellany 8(XCIV), https://doi.org/10.5962/p.310835.

View This Item Online: https://www.biodiversitylibrary.org/item/276320

DOI: https://doi.org/10.5962/p.310835

Permalink: https://www.biodiversitylibrary.org/partpdf/310835

\section{Holding Institution}

Museums Victoria

\section{Sponsored by}

Atlas of Living Australia

\section{Copyright \& Reuse}

Copyright Status: Public domain. The BHL considers that this work is no longer under copyright protection.

This document was created from content at the Biodiversity Heritage Library, the world's largest open access digital library for biodiversity literature and archives. Visit BHL at https://www.biodiversitylibrary.org. 